\title{
Features of legal support for the operation of small atypical Ukrainian coal mines under contractual conditions of a public-private partnership
}

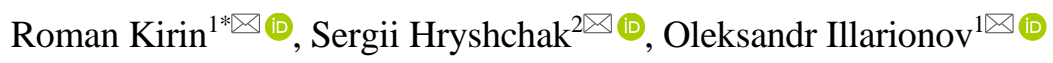 \\ ${ }^{I}$ V. Mamutov Institute of Economic and Legal Research of NAS of Ukraine, Kyiv, 03057, Ukraine \\ ${ }^{2}$ Dnipro University of Technology, Dnipro, 49005, Ukraine \\ *Corresponding author: e-mail kirinrs62@gmail.com, +380505716399
}

\begin{abstract}
Purpose is to study and develop the economic and legal model of small atypical coal mines basing upon the analysis of the operations under contractual condition of public-private partnership as well as upon adequate legislative and engineering support in the context of pressure of internal and external factors.
\end{abstract}

Methods. The study has been carried out with the use of economic and legal approach being the evaluation of actual technoeconomic activities of the two market participants, i.e. small atypical mine and state-owned mining enterprise, identification of their interaction problems and determination of obstacles preventing from their cooperation. Component two of the approach is the analysis of available (legal) mechanisms for regulatory management of relations between the two market participants as well as formulation of appropriate proposals to conclude such an economic agreement which would satisfy demands and involve governmental interests and interests of a private investor (partner).

Findings. It has been determined that economic contracting under the conditions of engineering as well as procedural and institutional operational dependence of a small atypical coal mine, and hypothetical liquidation of a state-owned coal mining enterprise is possible under the conditions and in accordance with the procedure by the legal system of Ukraine. A type of agreement concerning mutual provision of services with the required appendices has been identified to normalize production activities, to control operational safety, and to minimize the socioeconomic results of such potential conservation (liquidation) of unpromising mines.

Originality. Innovative model of legal support for a small atypical mine establishment and operation has been developed which has never been formulated in such a proposed manner in Ukrainian scientific sources, and in the foreign ones.

Practical implications. The study results may be applied to develop business relations in the context of a coal industry, i.e. to establish small atypical mines, to solve the severe socioeconomic, investment, and environmental problems of coal mining Ukrainian regions with unpromising mining objects, and to exercise influence on the contents of a concept aimed at extraction industry reforming as well as its implementation plan.

Keywords: small atypical mine, state-owned coal mining enterprise, public-private partnership, contractual terms

\section{Introduction}

Economic recovery in Ukraine at the beginning of the $2000^{\text {th }}$, increase in fuel and power resource demand (in particular, in coal of different grades for power industry, metallurgical industry, public utilities, and domestic consumption) favoured the origination and further development of business relations in the context of such specific branch of management and subsurface use as coal mining. It goes without saying that not construction of new coal mining enterprises or reconstruction of available ones is meant; by that time, all more or less profitable and/or restored mines were either private property or leased out as integral property complexes (further, IPCs). Thus, mechanisms of such a public-private partnership as IPC leasing have helped solve problems of the lack of financing, the established coal market, facilitation on the part of government and local authorities etc. However, they could not be considered as such due to not rare examples of their technical dependence upon IPC of a state-owned coal producer (further, SOCP) which has already been liquidated, being liquidated, or that designated to liquidation. In this context, the fact should be stated that a procedure of SOCP operation termination in the form of its liquidation is a complex of high-cost activities.

Re-engineering practices in Poland show that the expenditures, connected with the exhausted mine liquidation, involve expenses for disassembly of equipment, disassembly of electric power lines and communication line, for measures intended to wreck surface constructions, to seal shafts, and to liquidate bore holes, pits, and mine drainage. Moreover, environmental measures, involving engineering solution of 
drainage problems as well as measures to prevent gasdynamic phenomena, are also cost ones. Nevertheless, the cost of socioeconomic protection of employees being fired is the most convincing share of the expenditures connected with a coal mine closure [1].

For instance, a new tendency in the form of tourism development is one of the features of Katowice city. Silesia City Center has been built at the territory of the closed Katowice-Kleofas mine. In perspective, it is planned to develop a technopark, to erect several shopping centres, and to construct a stadium within the former industrial territories [2].

Practices of such foreign countries as USA, RSA, and PRC show that the efficiency of small atypical mines (SAMs) can be achieved owing to the implementation of low-cost coal mining methods adapted to the conditions of finite-reserve mine fields with irregular-shaped geometry, variable hypsometry of coal seams etc. [3], [4]. At the same time, organization of SAMs and their operation is restricted by the lack of technological and engineering solutions concerning penetration, development, and extraction of coal seams within the mine fields as well as concerning adequate legal support of business activities of such objects. The known mining methods, applied abroad to mine coal in SAMs, cannot be applied mechanically in Ukraine having neither equipment nor techniques for efficient implementation of the world operational procedures.

Ukraine possesses $10 \%$ of the proven $10 \%$ of European reserves, and $3 \%$ of the world ones. Taking into consideration such huge reserves and gas import problems, the government does its best to support even unprofitable and unpromising mines. Expenditures, connected with the back of unprofitable mines, are running high. To a great extend, they support corruption schemes when coal, mined illegally in kopankas (i.e. unlawful shallow holes) is marketed as the subsidized coal by SOPC. From the viewpoint of political and social impacts, it should be remembered that shock restructuring in Great Britain has become possible in particular owing to their coal industry concentration within one region to compare with Poland and Ukraine where sudden closure of mines would swinge disproportionately populous region specifically depended upon coal industry [5].

\subsection{Statement of the problem}

Approval of annual budget restructuring programs for coal industry with liquidation of coal mining associations rather than certain mines was focused on the avoidance of surplus coal products in the Ukrainian market. However, external factors (i.e. WTO accession by Ukraine with its gradual refuse from governmental support of coal industry; and pressure on the part of the world coal market with its significantly lower prices and higher quality) and internal factors (loss of almost $60 \%$ of coal mining capacities; economic diversification plans; and the necessity to develop infrastructure of post-mining regions with overcoming of socioeconomic results of such managerial decisions) factored into sizeable deficiency in the internal market; the deficiency is critical in terms of certain coal grades. Approval of basic regulatory legal acts for coal industry restructuring was not developed in the process of formulation of the required subordinate legislation, replacement of obsolete regulations and standards by new ones etc. Hence, establishment of SOCEbased small atypical coal mine should involve the use of fundamental notions while interpreting them in the context of each individual case. Unprofitable mines should be transformed first as the technically integrated and organizationally separated (unified) property portfolio (further, UPP) of tools and resources for mineral extraction, and for construction and operation of objects with the use of mining methods (i.e. mines, ore workings, open pits, open casts, preparation plants etc.) understood by the Mining Law of Ukraine (further, MLU) as a mining enterprise [6].

In turn, according to Article 1 of Law of Ukraine of 12.04.2012 \#4650-VI "On the features of privatization of coal mining enterprises" (later, special privatization law), coal mining enterprise is considered as a mining plant where underground or surface coal mining is the basic economic activity. A mining plant may include mines, mine offices, open casts, and other auxiliary separated units [7]. Single mine working (system of mine workings) or a mine working, being a part of or a mining enterprise of some other one, and used for mineral extract or other purposes as well as buildings (constructions), connected with them technologically, are involved in a "mining object" notion [6].

Government proposal relies on the idea that in the context of reforming of the state-owned coal enterprises, it is assumed to divide the mine facilities into following groups [8]:

1. Promising mines having:

a) considerable reserves of commercial coal;

b) a potential to become profitable promptly.

2. Unpromising mines divided into the two subgroups:

2.1. Mines to be conserved (if there is no any purchaser during privatization when technical and economic feasibility is available making it possible to restore their commercial activities in the short-run with no government support) are mines with:

a) low cost/performance ratios;

b) high deterioration level of the mine facilities;

c) the required significant capital investment to make the a mine profitable;

d) considerable coal reserves.

2.2. Mines to be liquidated are the mines which:

a) develop residual commercial reserves;

b) cannot operate profitably.

The systematics offer opportunities to identify the mines which assets can be leased out partially; certain share of the assets can be in joint use.

Succeeding task of the Cabinet of Ministers of Ukraine (further, CMU) is to develop and approve in accordance with the established procedure, by the $30^{\text {th }}$ of April 2020, a concept of mining branch reforming as well as a schedule of measures to implement it. Among other things, the process should involve preparatory measures and conduction of:

a) privatization of promising coal mines;

b) restructuring (conservation) of unpromising coal mines [9].

As it is seen, the instruction ignores the establishment of small atypical coal mines (further, SACMs).

However, realistic prerequisites have been developed currently to renovate establishment processes as for SACMs; moreover, such regulations, based upon consideration of practices of SACMs by the paper, should become the integral part of the modernized concept of the mine branch reforming as well as measures to implement it.

Nevertheless, minimum scientific interest is shown to the problem of operation of SACMs. It is considered from a viewpoint of eco-economic features of Donbas coal mine liquidation where authors state that liquidation procedure of 
mines is rather lengthy process ongoing even after the mine shut down its extraction process. In this context, approaches to minimize negative effects of mine operation are analyzed inclusive of disturbance of a hydrological regime [10].

It is also proposed to ground further functioning of coal branch on a model of a public-private partnership (further, PPP) which, the author believes, is the prerequisite for successful operation of the coal branch as well as the national economy on the whole. However, the statement is not topical for the current legal terms since the tendency has been excluded from the appropriate legislative act [11].

While making eco-economic evaluation of potential mining of residual coal reserves by small mines, A.V. Bardas brings up a problem that any procedural and institutional measure will be inefficient without improvement of living conditions within the depressed regions; the problem needs the development of a program for a mine staff employment as well as control over its implementation [12].

In his paper, R.S. Kirin calls attention to a disbalance between statutory and regulatory requirements for deposit developers, and instructions by mining regulations as well as subsoil legislation. The author proposes to classify the requirements in terms of subject-object structure, and in terms of period (stage) of the subsoil use [13].

\subsection{Objective of the paper and problem definition}

Objective of the paper is to analyze and represent practices of SACM in the contract PPP terms as well as relevant legal support under the effect of internal and external factors.

The abovementioned involves execution of following tasks:

- analysis of the normative legal base providing regulation of relation in the field of coal mining in the contract PPP terms;

- study of operational characteristics of a small atypical coal mine, and determination of dependences with a SOCE being under liquidation (liquidated);

- economic and legislative characterization of activities of both types of the enterprises;

- development of possible legislative tools regulating relations between a SOCE being under liquidation (liquidated) and SAM, and determination of the most optimal type of economic contract for the group.

Order of the studies depends upon logic of the listed tasks, structure, and definitions by the MLU as well as by other acts of the current (or former) legislation, and upon operation procedures of SAMs.

\section{Results and discussions}

Before the Law of Ukraine "On the public-private partnership" of 01.07.2010 \#2404-VI [14] was adopted, problems of provision of integral property complexes of coal enterprises were solved at a level of the Law of Ukraine "On the lease of public assets and municipal assets" [15] (further, general leasing law), were concretized by terms of leasing agreements as well as special orders by the Ministry of Energy and Environmental Protection of Ukraine (former Ministry of Fuel and Energy of Ukraine, Ministry of Coal Industry of Ukraine). For instance, IPC of a seam slope could be a leasing object with the issued symbol and number, and surface objects (i.e. industrial sites, skips etc.) separated from IPC of a coal mine which has already been closed down or being prepared for its closure.

\subsection{Novels of the national legislation in the field of public-private partnership for privatization and leasing}

In the context of the adoption of a new version of the Law of Ukraine "On concession" of 03.10.2019 \#155-IX [16] (further, concession law), provisions of the Law of Ukraine "On the Public-Private Partnership" can be applied if only they are directly arranged by the concession law.

Moreover, legal groundwork of the field, being the study object, has experienced essential modifications. In short, they are:

1) PPP, which has been used before to prospect, explore deposits, and mine them (besides those implemented in terms of production sharing contracts) is excluded from the PPP application under the law \#155-IX of 03.10.2019;

2) by the decision of the public partner, PPP may be applied in other areas of interests, involving provision of socially important services, not including those types of business activities which, according to the law, may be provided exclusively by the national enterprises, offices, and organizations; PPP is applied taking into consideration particularities of the legal regulation as for specific objects, and specific activity types determined by the law;

3) force of the concession law cannot be applied for projects involving prospect, exploration, and extraction of minerals; title of the Law of Ukraine "On the Features of Lease or Concession of the State-Owned Objects of Fuel-Energy Complex" has been replaced by "On the Features of Lease of the State-Owned Objects of Fuel-Energy Complex" (further, special leasing law);

4) application area of the special leasing law has been identified as follows: land-lease of a fuel-energy complex (further, FEC) not regulated by the law, are subject to regulation by Civil Code of Ukraine, Commercial Code of Ukraine, Land Code of Ukraine, general leasing law, and other legislative acts;

5) for the purposes of the special leasing law, such a term as "objects of fuel-energy complex" is used for the integral property complexes (further, IPCs) or for a system of IPC enterprises, and their structural subdivisions (i.e. branches, production units, and districts). They provide and are sufficient to carry out business activities in the field of coal and lignite mining, and their processing. List of assets, covered by the FEC object and is intended to be leased, is stipulated with the help of a relevant agreement;

6) leasing relations of FEC objects, being state-owned, are regulated by general leasing law taking into consideration the peculiarities, stipulated by a special leasing law; IPCs of enterprises and their structural subdivisions are leasing objects according to the general leasing law;

7) the assets, being the material basis of the property of Ukrainian nation inclusive of specially designated places or objects for waste disposal (i.e. disposal sites, waste storages, landfills, complexes, constructions, subsoil areas etc.), cannot be considered as leasing objects.

While digressing, it should be noted that the paper applies SPC and IPC simultaneously. First, it depends upon their use by the relevant regulatory legal acts. Second, they are considered as identical notions since meaning one and the same economic and legal category.

As for the subsoil area use, it stands to mention that according to Article 16 of Code of Ukraine on Subsoils of 27.07.1994 \#132/94-BP [17] (further, CS) as well as according to the abovementioned changes, the economic agent 
contracted for SOCE IPC obtains special permission while re-legalizing special permissions to use the subsoil issued for coal mining enterprises of the government sector which IPC was leased out. The permissions are issued in favour of an enterprise leased out IPC of the coal mining enterprise for the term of the special permission with no tendering process.

While leasing out IPC of a SOCE and during a period of the special permission legalizing to use subsoils and mine allotment, the leasee performs mining of coal and/or lignite within the object leased out on the basis of the current special permission to use the subsoils and mine allotment of the SOCE which IPC has been leased out but maximum for the period of 12 months as from the date of the leasing contract formation.

Hence, leasing legislative operation conditions of atypical coal mines is in its essence the only alternative to the privatization regime actualized according to the Decree of the President of Ukraine "On the Interim Measures to Implement Reforms and Enhance the State" of 08.11.2019 \#837/2019. The Decree puts in charge of the CMU to take measures as for the development and adoption in the prescribed manner a concept concerning coal industry reforming as well as its implementation plan which should involve, among other things, preliminaries and privatization of promising coal mines, and restructuring (conservation) of unpromising coal mines. The abovementioned should be put into practice by 30.04.2020 [18].

According to Article 4 of the special privatization law, following objects are considered as privatization targets:

a) coal mining enterprises as SPCs;

b) mines (mine offices) as SPCs;

c) surface mines as SPCs;

d) state-owned shares within the authorized capital of joint-stock companies established during SOCE privatization or corporatization.

According to Article 16 of CS, special permissions to use subsoils are given to the economic agent, who privatized SOCE according to the special privatization law by means of re-legalization of special permissions to use subsoils granted to the specified SOCE in favour of the economic agent for the term of who privatized it for the period of the special permission validity with no tendering process.

In the context of such legal support of certain property share allocation (according to a separation balance sheet) a problem of legal succession for subsoil use within technical boundaries of the mine being established was solved according to the special permission to use the SOCE subsoils. In such a case, certain property share (namely, a hoister, the main haulage drifts etc.) may be remained in the joint use of two legal entities but being essentially SPC. The facilities are applied by them to descend bulky materials and equipment, and to hoist. Mine workings for intake air delivery to a ventilation system may also be used jointly (since the ventilation system is common for the whole property portfolio being maintained by a common site of ventilation and occupational safety (further, VOS). Such coal mining enterprises (i.e. operating, newly established, closed down, or being in the process of its closure, or that being in the process of its liquidation) may have a general emergency response plan which corresponds entirely to Article 27 of MLU, and conscience clause 3.1.6. of Safety Rules in coal mines approved by an Order of the National Labour Safety Supervisory Committee of Ukraine "On the Adoption of Safety Regulation in Coal
Mines" of 16.11.2004 \#257 [19]. Later the Rules were reformed and state in a new version (see Order of the National Committee of Ukraine on the Industrial Safety, Labour Protection, and Mines Inspectorate of 22.03.2010 \#62 [20]). As for the organizing the activities of two and more enterprises in the context of the integral property complex they did not experience any changes.

\subsection{Problems of joint business activities of the state-owned coal mining enterprise and a small atypical coal mine}

As it has been mentioned, SOCE may be at different liquidation stages except physical one. In this context, a Project to liquidate the coal mine as a legal entity and a mining object may be developed. Until now, the problem of such coexistence of two enterprises as well as subsequent legal regulation of those SPC shares which operation will continue even if physical liquidation of SPC residuals take place (i.e. extinguish of mine workings; their flooding) has not been solved. Intrinsically, the SPC parts, responsible for drainage, airing, descent of bulky materials and their hoisting, should be signed off to the newly established enterprise with ringfencing of its certain shares. From the legal viewpoint, engineering viewpoint, and economic one it is expedient to solve the problem while developing and implementing a coal mine Construction (Reconstruction) Project. The current legislation does not involve any other solutions of the problem. If such a situation happens, the problem will be solved (and has been solved) in the context of individual projects being unconducive to their unification and mass implementation. Following the results, the abovementioned hinders progress of business relations in the coal industry as well as SAM establishment.

It should be mentioned (and the statement is technically justified) that separation of ventilation system and/or drainage system may become an impossible process. For instance, such separation may factor into the impossibility of air supply due to its limited velocity along cage shafts etc.

If SOCE is under its liquidation then mining operations are abandoned. As a rule, the SOCE has not a license (i.e. special permission) to perform specific activities (i.e. blasting operations) which prevents from solving a problem of additional expansion of mine workings, increment of their parameters for normative airing, bulky cargo traffic etc. In the context of a newly established enterprise (i.e. atypical small mine) availability of such an authorization document may be a cumbersome idea adding extra expenses connected with organization of blasting operations and their performance which may result in the decreased economic value of the residual coal mining.

How is it possible to solve the problem of coexistence of a SAM with SPC of an enterprise being under liquidation or has already been liquidated? It should be mentioned that physically a coal mining enterprise may remain unliquidated but transferred to the specialized economic agent to which balance sheet, for instance, drainage complexes, influencing hydrological situation of seams and pillars, were transferred.

Conclusion of a cooperation contract is one of the most reasonable ways to rationalize relations between a newly established SAM (possessing a share of the property complex) and a coal mining enterprise being under liquidation (or which has already been liquidated) or economic agent to which balance sheet the shares of the property complex, 
exercising a significant influence on the activities of other mining enterprises, were transferred. Analysis of provisions of the current statutory wording of the Law of Ukraine "On the Public-Private Partnership" of 01.07.2010 \#2404-VI, and the special leasing law mean that it is possible to rationalize such relations by means of the specific economic agreement.

Economic and legal characteristic of activities of the established SAM and SOCE being under liquidation (has already been liquidated) is required to determine a potential for such an agreement conclusion and its type determination. In practice, a problem of cooperation of the enterprises was solved by means of making a cooperation contract which framework has not been developed thoroughly involving abuse risks as well as various lawlessness types confirmed by the activities of legal bodies, revenue authorities, and law courts.

Notwithstanding, cooperation agreement made it possible to perform joint development operations and mining ones within the sites, adjoining SAM seams, haulage gates, junctions of slopes and haulage gates etc. Such cooperation agreements were registered by territorial bodies of the State Taxation Service of Ukraine. The agreement had appendices of participatory inputs, amendments by the public enterprise and SAM etc. Framework of the cooperation agreement made it possible to issue joint SOCE and SAM orders as for the safe mining ensuring. Moreover, the orders also settled problems of a proper control over labour safety and occupational safety (as a rule, it was responsibility of a joint VOS site). In addition, duties and charges of the cooperation were determined in terms of the agreement and regulations by the applicable law. In this context, according to Article 19 of the MLU, the two enterprises acted relying upon a mine allotment as well as the special permission to use the subsoil (i.e. mineral mining) issued by the SOCE. In turn, as a legal entity, SAM has been special identified in the capacity of a legal successor in terms of IPC of the seam incline as well as objects of its industrial site. Hence, the issue concerning the right of the subsoil use within the newly established mine, was deciding as well.

However, after the beginning of 2006 such cooperation contracts started to be dissolved commonly by the agreement of the parties. As a result, small mines began apply numerously the Ministry of Environmental Protection of Ukraine for re-legalization of the special permission to use the subsoil. At that time, the problem was solved in a very short time ( 3 to 5 months); within technical boundaries, the majority of SAMs obtained such special permissions and continued their activities legally. Re-legalization of the special permission has helped develop a proper mining schedule for that year as well as for subsequent ones and follow it.

At the same time, dissolving the cooperation agreements has complicated activities by SOCEs since they invalidated use of objects transferred to SAMs (i.e. haulage gates, cages etc.) for their own purposes. In terms of the concluded contract, continuation of activities of both enterprises (i.e. SOCE and SAM) is unlawful since according to Point 2 of Article 1130 of the Civil Code of Ukraine (further, CCU), joint activities should involve a common purpose [21]. In this context, extraction of minerals (i.e. coal) and derive profit from the activity were objectives of the cooperation. The fact of the SOCE liquidation Project development means that further economic activities of the enterprise will be phased down. The matter is that according to Point 3 of Liquidation Procedure of unprofitable coal mining and coal processing enterprises, approved by the Order of the Cabinet of Ministers of Ukraine of 27.08.1997 \#939 (in the wording of the Order of CMU of 06.07.2002 \#938 as amended [22]) liquidation of a mining enterprise involves implementation of measures intended to phase down economic activities; to get its production facilities under a state guaranteeing safety of the staff, property, and environment as well as social protection of employees to be fired; and to solve other socioeconomic problems. Sub-paragraph 3 of Point 6 of the mentioned Procedure provides the following: liquidation project of a coal mining enterprise should contain proposals concerning capabilities to restart mining operations; to use the mine workings, buildings, and constructions; to implement measures intended to avoid hazardous impacts on the operating enterprises, the environment, and human health; and to overcome negative socioeconomic results of the liquidation.

The problem of taking measures to stop potential impacts of SOCE liquidation and to conserve a joint ventilation system, a joint VOS site, and to continue possibilities for the state-owned enterprise (or its legal successor) to descend and hoist bulky materials and facilities is important. Moreover, it is still topical in the process of both development activities aimed at the SOCE liquidation as a legal entity and its physical liquidation as well as conservation.

Dissolution of the cooperation agreements complicated relationship between enterprises being interdependent technically. The situation of technical dependence of business activities of the enterprises had to be settled. According to Point 1 of Article 67 of the Business Code of Ukraine [23] (further, BCU), interrelations of enterprises in all business areas should be based upon agreements. Therefore, according to the current law, the available problem should be resolved by means of execution of a business contract being without prejudice to the current Ukrainian legislation. One of the contract objectives is eliminate (to minimize) adverse effects of possible deactivation of SOCE and its liquidation. The conclusion has been formulated while preparing juridical science-based expert opinion upon the request of Sodeistviie PC (Torez, Donetsk Region) by O.O. Ashurkov \& O.Yu. Illarionov (2006). The conclusion has been implemented to settle relations between the state-owned enterprise Shakhta 3-bis and Sodeistviie PC (a small atypical mine Nikolaievskaia).

According to Point 2 of Article 67 of BCU, any enterprise is free to choose a subject of an agreement, a definition of liabilities, and other business relations not contradicting Ukrainian legislation.

For more than 15 years of BCU operation, numerous legislative changes were made inclusive of those for Article 75. Currently, in accordance with Part 5 of Article 75 of $\mathrm{BCU}$, no state-owned commercial enterprise (SOCE is the state-owned commercial enterprise) has a right for free transition of its property to other legal entities or citizenry except as required by a law. State-owned commercial enterprise may alienate property, being a part of the key assets, if only it has a prior consent of the body to which managerial sphere it belongs, and on a competitive basis only unless otherwise established by a statute. State-owned commercial enterprise has a right to dispose of the property, belonging to the key assets, only within terms of reference, and in the manner provided by BCU. In this context, the legislation does not limit a dispose of the property for the provision of contractbased services to other legal entities. The leased (own) pro- 
perty (for instance, hoisting units, haulage drifts etc.) may be used for provision of services to SOCE (or its legal successor). In turn, two enterprises may have a common ventilation network. Consequently, SOCE has a right to render services as for the SAM mine working airing or for the small mine service by a common VOS site. The abovementioned mutual services are stipulated by regulation of implementation of business activities of two enterprises. The services may become a subject of the alleged business contract.

Before the start of the state property privatization in FEC (which did not take place on the planned scale), assets of a SAM was on a lease. Contract of tenancy, concluded between the SAM as a legal entity, and Regional Department of the State Property Fund of Ukraine, has become the legal foundation to use the property. Among other things, terms of such an intrinsically standard contract for the lease of a certain share of SOCE assets involved a condition that the leasing holder has a right to control availability, state, tendency, and efficiency of the state-owned property use. Consequently, the leasing holder may obtain information concerning the property application for provision services to other economic agents. In this context, neither tenant of the property (i.e. a small mine) nor SOCE (i.e. its legal successor-liquidator) has the alternative to receive the listed services from other economic agents. Introduction of structural changes (for instance, redesign of skip shafts to descend outsize loads etc.), which can be involved by projects of SOCE liquidation, will results in extra significant expenses due to engaging of a developer as well as a contractor authorized to carry out special activities. Moreover, liquidation projects usually involve block structure installing between mine workings of the two enterprises which implies the necessity to assemble own ventilation equipment, and to construct both ventilation shaft and ventilation system of SAM.

According to Paragraph 1 of Point 18 of Liquidation Procedure of unprofitable coal mining and coal processing enterprises, approved by the Order of the Cabinet of Ministers of Ukraine of 27.08.1997 \#939, new job formation at mining enterprises is one of the measures intended to avoid negative socioeconomic results. Continuation of a common VOS site as well as provision of airing services by SAM will save jobs required to perform such activities.

Summing up, we can state that the specific technical conditions stipulating business activities of two enterprises and their technological interdependence need provision of mutual services, i.e. settling of SAM-SOCE relations by means of business contracting (involving its compulsory compliance with Ukrainian legislation).

\subsection{Analysis and selection of economic-juridical agreement of the public-private partnership}

The variety of business relations, occurring between enterprises, gives rise to the necessity of their consolidation with the help of different types of economic agreements. The legal system (namely, Article 67 of BCU) enacts into law freedom of parties to conclude such an economic agreement which will result in the achievement of maximal commercial or other effect from the mutual activities according to the object of the concluded contract, and its terms. However, such a freedom in the contract conclusion is relative one. The matter is that the legislation may identify indicative rules and obligatory rules for the agreement conclusion as well as the required list of the substantive provisions. Moreover, the legislation has a right to add other requirements to the terms. In this context, for instant, the agreement has to regularize activities, connected with the increased risk of emergency situations, and danger to life and health according to a List of activities with heightened danger, approved by the Order of the National Committee of Ukraine for Supervision of Occupational Safety and Health of 26.01.2005 \#15 [24]. In this context, content of economic agreement is influenced by a mutual technical dependence of economic agents.

Scarcely ever business relations between enterprises, complicated by the technical interdependence, can be normalized with the help of economic agreement which object is joint use of facilities. Object of the agreement may also cover services by a joint structural unit being other than property. In this context, VOS site is meant. Conclusion of such a contract should identify a list of assets intended for the joint use. Moreover, object of a one contract has to combine VOS site maintaining of a SAM, and airing of mine workings of a technical field of the mine by ventilation SOCE network on the one hand, and provision of services to descend and hoist bulky material using the listed assets belonging, for instance, to a small atypical mine. Conclusion of economic agreement concerning mutual provision of services is one of the solutions of the problem. The inference has been drawn as a result of preparation of the abovementioned economic and legislative science-based expert opinion.

According to Point 7 of Article 179 of ECU, economic agreements are concluded in terms of rules determined by CCU taking into consideration the peculiarities defined by ECU and other legislative acts. Article 180 of ECU identifies essentials of economic agreements being its content and those focused on the determination of financial liabilities both agreed by the parties and those identified by Ukrainian legislative acts.

Any agreement should involve determination of terms according to the current Ukrainian legislation. While concluding economic agreement, the parties have to finalize, at least, its subject, price, and duration. Subject terms should determine names of services, provided by both parties as well as their quality (Point 4 of Article 180 of ECU). According to the service agreement, one party (i.e. contractor) has to provide a service (services) by an order of another party (i.e. customer). The service (services) is consumed in the process of a certain act or certain activity performance; in turn, a customer undertakes to pay the contractor a service unless otherwise provided by the contract (Point 1 of Article 901 of ECU).

The contract duration is determined by the agreement of the parties unless otherwise provided by the contract or by other legislative acts (Article 905 of ECU). According to the standard leasing agreement terms, it lasts for 5 years. Hence, SAM-SOCE contract term is limited by SPC leasing agreement term. Lease renewal will be a basis to prolong mutual service agreement or to conclude a new one (its revised version).

It is important to note that relations of the two enterprises are detailed in appendices which can be listed conventionally in such a way:

1) procedure of rendering services for descending and hoisting of bulky materials and facilities;

2) procedure of rendering services for maintenance by VOS site;

3) procedure of joint ventilation system use;

4) calculation of the rendered mutual services in terms of money. 
When concluding an agreement on mutual service provision and compiling appendices, it is required to issue a new version of a joint SAM-SOCE order (legal successor of the latter) in the new edition "On the cooperation aimed at the safe mining provision". The documents concretize the mutual services being rendered, detail rights and liabilities of parties in terms of the agreement, and harmonize activities of the enterprises with legislative requirements intended to reduce the possibility of emergencies and to follow occupational safety as well as preventive fire-fighting regulations.

It should be noted that according to Article 652 of CCU, if substantial changes take place in the circumstances the parties were guided while concluding, the contract may be either amended or dissolved by agreement of the parties unless otherwise provided by contract or follows from the essence of the liabilities. Change in the circumstances is considered as a substantial one provided it varied so much that if the parties could foresee it they would not conclude a contract or would conclude it in other terms. If a contract is dissolved due to substantial changes in circumstances then a court, being guided by any party, identifies consequences of the dissolution relying upon the necessity of fair sharing of expenditures by the parties resulting from the contract execution (Point 3 of Article 652 of CCU). By a decision of a court, contract amendments, resulting from substantial changes, are allowed in exceptional cases when the contract dissolving contradicts public interests or such a dissolving incurs losses to the parties exceeding drastically the cost required for the contract execution subject to conditions varied by a court.

It should be mentioned that under the special technical and legislative conditions of business activities of the both enterprises, i.e. their technical dependence, the type of a mutual service contract as well as the supposed list of its appendices will settle completely relations between SAM and SOCE (its legal successor).

\subsection{Legal and technical issues of relations of subjects as for the liquidation project}

The next relevant problem is: whether SAM has a right to make proposals to a project of SOCE liquidation under the available legal and technical conditions? If so what is its extent and stages involved? According to Paragraph 3 of Point 6 of Liquidation Procedure of unprofitable coal mining and coal processing enterprises, approved by the Order of the Cabinet of Ministers of Ukraine of 27.08.1997 \#939, such a liquidation project should include proposals concerning continuation of mining operations, use of mine workings, buildings and constructions as well as measures intended to avoid negative influence on the operating enterprises, environmental conditions, and human health. Moreover, measures to overcome negative socioeconomic results of the liquidation must be involved as well.

If leasing agreement of IPC was concluded before the SOCE liquidation project started, then a small atypical mine as the interested party (i.e. an enterprise impacted by the SOCE liquidation in terms of its economic activities) has a right to make proposals concerning implementation of the measures both at the stage of the liquidation project scheduling and in the process of the project execution. Otherwise, if the authorized governmental bodies neglect possible risks to economic activities of a SAM in the process of SOCE liquidation then the interested enterprise may make proposals concerning elimination of adverse effect on its activities by means of making relevant proposals to the project of coal enterprise liquidation.

Liquidation project of a coal enterprise is based upon the Standard of the Ministry of Fuel and Energy of Ukraine titled as "Liquidation project of coal mines in Ukraine". Its composition and contents are approved by a relevant Order "On the approval and implementation of the Standard by the Ministry of Fuel and Energy of Ukraine "Liquidation project of coal mines in Ukraine. Composition and contents of the Project" of 16.11.2004 \#721 [25].

Commercial coal mining within the allocated seam for profit is the key tendency of economic activity by a SAM. In turn, SPC use of the enterprise to terminate economic activities of the enterprise, to transform technical field of the mine into a safe object, considered from the viewpoint of the influence on the environment, and human health and from the viewpoint of elimination (minimization) of negative impact on the activities of operating enterprises, are the key performance tendencies of a legal successor, determined according to the legislation, after the Project of SOCE liquidation started.

Each stage of SOCE liquidation involves a risk to economic activities by a SAM within technical boundaries of its field; being an enterprise, adjoining that one being liquidated, the former has a right to make proposals to eliminate such potential negative influence at all liquidation stages even if the liquidation project has not been approved yet and the authorized governmental body has not made its final solution concerning the SOCE liquidation. Negative effect of SOCE liquidation on the economic activities by the SAM will complicate social decisions in the process of the SOCE liquidation since the decisions are quite important for the region.

According to the Point 1.14 of the Instruction on the Procedure of Liquidation and Conservation of Enterprises Engaged in Mineral Extraction (in terms of organization of safety, efficient use, and subsoil protection), approved by a Resolution of Gostekhnadzor of the USSR of 11.07.1985 \#28 (NPAON 00.0-5.05-85) [26], such a project for mine working liquidation may not to be developed if there is a body (enterprise) interested in the further use of the underground mine workings. In other words, if the SAM is interested in the continued operation of a ventilation network after the SOCE liquidation then it has a right to make relevant proposals concerning the coal enterprise liquidation.

Then, such a proposal to terminate potential negative influence of SOCE liquidation becomes maintaining a joint ventilation system, joint VOS site, and saving the opportunity for the SOCE (or its legal successor) to descend and hoist bulky materials and facilities. The aforementioned is topical in the process of preparation activities intended to liquidate the SOCE as well as in the process of physical liquidation and conservation of the enterprise. Establishing legal relations between SAM and SOCE by means of economic agreement concluding in terms of the abovementioned will develop a basis for a normal and safe coal mining activities of the SAM according to the special permission; in turn, that will help the SOCE (or its legal successor) solve its technical problems concerning the enterprise liquidation.

According to Point 1.6 of the Instruction on the Procedure of Liquidation and Conservation of Enterprises Engaged in Mineral Extraction (in terms of organization of safety, efficient use, and subsoil protection), approved by a Resolution of Gostekhnadzor of the USSR of 11.07.1985 \#28, the 
procedure of any enterprise liquidation should involve consideration of a problem of further use of mine workings for other economic purposes. Such a purpose may be both the continued operation of a ventilation network to provide regulative standards for airing of the SAM mine workings in terms of the concluded agreement and prolongation of the agreement concerning the ventilation network use after the enterprise is liquidated.

Relying upon the abovementioned characteristic of economic activities (both present and future), it is possible to draw a conclusion that the Liquidation Procedure of unprofitable coal mining and coal processing enterprises, approved by the Order of the Cabinet of Ministers of Ukraine of 27.08.1997 \#939, covers recognition of a SAM as an enterprise influenced adversely by the SOCE liquidation. In this context, if the SAM proves the availability (potential) of such influence, it has the reasoned right to make proposals to the liquidation project as for the influence elimination (minimization) at each stage of the project development as well as each stage of its implementation as it has been mentioned above.

Final approval of the SOCE liquidation project will become the legal foundation for the relevant ministry to issue an order as for the enterprise liquidation as well as the foundation to determine a legal successor of the SOCE during a year. The legal successor will implement the duties assigned by the Procedure.

According to the Article of the MLU, the persons, guilty of a violation of the Mining Legislation, are brought to disciplinary liability, civil liability, and criminal liability with reference to laws and regulations of Ukraine. The following is considered as such law violations: making such engineering decisions not satisfying the requirements of the Mining Legislation. Among other things, that concerns enterprise right to make proposals to the liquidation projects at each stage of its development and implementation to eliminate (minimize) negative influence on its activities. The law violations may give occasion for compensation of losses according to the Ukrainian legislation if they take place (Article 50 of MLU).

\section{Conclusions}

Small atypical mines may make proposals to SOCE liquidation project at each stage of its development and implementation to eliminate (minimize) negative influence of such an enterprise on the SAM activities. Namely, aftereffects on economic activities by the SAM are meant if services intended to air its mine workings are not provided due to the potential liquidation of the joint ventilation system being under the jurisdiction of SOCE.

In this context, the questions, arising from the essence of operations, performed by SAM, to provide labour safety and to maintain the mine working safe are also important. Should the enterprise have a license for construction operations in addition to the Permission to continue hazardous operations? How can the documents be correlated? It should be mentioned that the Mining Development Program of an enterprise is compiled and agreed annually with the State Mining Supervision Authority. The Program includes the Detailed Report with a list of operations to be performed as for the each mined seam. Hence, according to the Detailed Report, activities are involved which can be identified as "mining operations". Time programs of the mining progress (both future operations and the current ones) are developed and approved according to the Regulations on the Development, Formulation, Integration, and Authorization of Mining Schedule and Subsoil Coal Losses during Extraction, approved by the Order of the Ministry of Coal Industry of the USSR of 30.12.1984.

Analysis of the listed documents and Safety Rules in coal mines makes it possible to characterize the activities, performed by an enterprise, as mining operations connected with mineral extraction (being its principal activity based upon the special permission and mine allotment), and maintenance of a mine working safe for the principal activity relying upon the priority during mining, i.e. prevention from such types of accidents as rock fall and rock burst (Article 26 of MCU). The characterized operations are considered as hazardous ones. The issue has not been regulated legally yet creating certain problems for SAM activities in the form of extra difficulties in the process of obtaining of sets of authorization documents.

Such a notion as "mining operation" is a volume one including both mining object construction (inclusive of set of operations to drive and support mine workings, i.e. construction of load-carrying constructions as well as protective ones) and activities to maintain the mine working safe (i.e. its repairing and retimbering). Construction of mining objects should be supported by a license for construction activities in accordance with the law. However, the repair (with no changes in the mining object purpose), namely retimbering of mine workings, i.e. activities to maintain them safe in the context of the principal economic activity being coal mining, needs not any licensing while subjecting to approval and obtaining a permit by the authorized agency (the National Service of Ukraine for Labour) according to the Law of Ukraine "On the Licensing System in the Field of Economic Activities" of 06.09.2005 \#2806-IV and other regulatory legal acts.

In the context of the abovementioned, the State Inspectorate of Urban Planning of Ukraine is not authorized to administrate adherence to license provisions in the process of construction of mining objects. The matter is that relying upon Article 10 of MLU, public supervision in the field of mining relations as for the compliance with the laws, mining operations, construction activities as well as liquidation or conservation of mining enterprises are controlled by the central executive authority which activities are administrated and coordinated by the CMU through a Minister of Social Policy. The State Service of Ukraine for Labour joins the activities inclusive of the implementation of public mining supervision.

To summarize, we can state that economic agreement conclusion in terms of the current technical situation (i.e. interdependence of economic activities of enterprises) as well as procedural and institutional situation (potential SOCE liquidation) is only possible under the terms and conditions determined by the legislation of Ukraine. To harmonize mutual relations of both enterprises, Point 1 of Article 67 of ECU is applicable stating that relations between enterprises can be regulated by means of economic agreement conclusion, namely the agreement of mutual service provision with the required appendices. Such an agreement normalizes activities of the enterprises; develops a legal basis to exclude possibilities of negative influence on the economic activities of a SAM if decision concerning SOCE liquidation is made; develops foundations for occupational safety and fire safety which correspond to the current legislation; and favour solv- 
ing certain problems to overcome socioeconomic results of the potential SOCE liquidation.

Problems of legal status of property, experienced its improvement (i.e., overhaul of equipment and its modernization), procedures of mine working filling; determination of potential losses for the enterprise and the state; and possibilities for a leasee of public property to transfer it to use by contractors (if the property is a part of the IPC) are the promising tendencies connected with formation and further advance of legislation concerning SAM activities on a contractual basis of PPP.

\section{Acknowledgements}

Authors of the paper express their gratitude to V.K. Mamutov, Doctor of Juridical Science, Corresponding Member of the NAS of Ukraine, the Honoured Lawyer of Ukraine, Director of Institute of Economic and Legal Research of NAS of Ukraine, and V.A. Ustymenko for scientific and advisory, and organizational assistance in the process of preparation of materials and pursuance of the relevant studies. Moreover, the authors express thanks to reviewers and editors for their valuable comments and recommendations concerning the improvement of the paper structure.

\section{References}

[1] Jarosz, J. (2009). Prawne i ekonomiczne aspekty procesu likwidacji kopalñwêgla kamiennego w Polsce. Zeszyty Naukowe Instytutu Gospodarki Surowcami Mineralnymii Energi Polskiej Akademii Nauk, (75), 59-69.

[2] Paszcza, H. (2010). Procesy restrukturyzacyjne w polskim górnictwie wĉgla kamiennego w aspekcie zrealizowanych przemian i zmiany bazy zasobowej. Górnictwo i Geoiniynieria, 34(3), 63-81.

[3] Amosha, O.I., Rassuzhdai, L.M., \& Poliansky, V.V. (2009). Foreign practices of coal industry restructuring and its results in Ukraine. Ekonomika Promyslovosti, (5), 199-205.

[4] Maldynova, A., Osmanov, Z., \& Galiyev, D. (2018). Formation of marketing strategy for promoting an innovative product. Journal of Applied Economic Sciences, 13(7), 1951-1958.

[5] Kopaty po-novomu. Yak modernizuvaly shakhty u Yevropi. (2014). Retrieved from https://lb.ua/economics/2014/12/15/289367 kopati ponovomu yak modernizuvali.html

[6] Mining Law of Ukraine of 06.10.1999 \#1127-XIV. (1999). Kyiv, Ukraine. Retrieved from https://zakon.rada.gov.ua/laws/show/1127-14

[7] On the features of coal mining enterprise privatization: The Law of Ukraine of 12.04.2012 \#4650-VI. (2012). Kyiv, Ukraine. Retrieved from https://zakon.rada.gov.ua/laws/show/4650-17

[8] On the recognition of the Concept of Reformation and Development of Coal Industry for the Year of 2020: Ordinance of the Cabinet of Ministers of Ukraine of 24.05.2017. (2017). Kyiv, Ukraine. Retrieved from https://zakon.rada.gov.ua/laws/show/733-2017-\%D1\%80
[9] On the Urgent Measures to Implement Reforms and Secure the State: The Decree of the President of Ukraine of 08.11.2019 \#837/2019. Uriadovy Kurier of 13.11.2019, (217).

[10] Amosha, O.I., \& Bardas, A.V. (2009). Features of liquidation of coal mines in the context of old industrial regions. Ekonomika Promyslovosti, (3), 34-37.

[11] Serdiuk, O.S. (2012). Alternative approaches to restructuring of Ukrainian coal branch. Naukovi Pratsi NDFI, (3), 115-121.

[12] Bardas, A.V. (2010). Ecological and economic evaluation of the potential to extract residual coal reserves by small mines. Efectyvna Ekonomika, (6).

[13] Kirin, R. (2019). Statutory and regulatory requirements in the process of mineral mining in Ukraine. Review and analysis. Mining of Mineral Deposits, 13(2), 59-65. https://doi.org/10.33271/mining13.02.059

[14] On the Public-Private Partnership: The Law of Ukraine of 01.07.2010 \#2404-VI. (2010). Kyiv, Ukraine. Retrieved from https://zakon.rada.gov.ua/laws/show/2404-17

[15] On the Lease of the State-Owned and Municipal Property: The Law of Ukraine of 03.10.2019 \#157-IX. (2019). Kyiv, Ukraine. Retrieved from https://zakon.rada.gov.ua/laws/show/157-IX

[16] On the Concession: The Law of Ukraine of 03.10.2019 \#155-IX. (2019). Kyiv, Ukraine. Retrieved from https://zakon.rada.gov.ua/laws/show/15520? find $=1 \&$ text

[17] Subsoil Code of Ukraine of 27.07.1994\# 132/94-BP. (1994). Kyiv, Ukraine. Retrieved from https://zakon.rada.gov.ua/laws/show/132/94-вp

[18] The Urgent Measures to Implement Reforms and Secure the State: The Decree of the President of Ukraine of 08.11.2019 \#837/2019. (2019). Uriadovy Kurier of 13.11.2019, (217).

[19] On the Approval of Safety Rules in Coal Mines of 16.11.2004 \#257: The Order of the State Committee of Ukraine for Supervision of Labour Protection of 16.11.2004 \#257. (2004). Kyiv, Ukraine. Retrieved from https://zakon.rada.gov.ua/laws/show/z0327-05

[20] On the Approval of Safety Rules in Coal Mines: The Order of the State Committee on the Occupational Safety, Labour Protection, and Mines Inspectorate of 22.03.2010 \#62. (2010). Kyiv, Ukraine. Retrieved from https://zakon.rada.gov.ua/laws/show/z0398-10

[21] Civil Code of Ukraine of 16.01.2003 \#435-IV. (2003). Kyiv, Ukraine. Retrieved from https://zakon.rada.gov.ua/laws/show/435-15

[22] The Procedure for Liquidation of unprofitable coal mining and coal processing enterprises approved by the Resolution of the CMU of 27.08.1997 \#939 (as amended). (1997). Kyiv, Ukraine. Retrieved from https://zakon.rada.gov.ua/laws/show/939-97-ח

[23] Economic Code of Ukraine of 16.01.2003 \#436-IV. (2003). Kyiv, Ukraine. Retrieved from https://zakon.rada.gov.ua/laws/show/436-15

[24] List of Hazardous Activities (NPAOP 0.00-4.12-2005) approved by the Order of the State Committee of Ukraine on Labour Safety Supervision of 26.01.2005 \#15. (2005). Kyiv, Ukraine. Retrieved from https://zakon.rada.gov.ua/laws/show/z0232-05

[25] Project for Liquidation of Coal Mines in Ukraine. Composition and Contents of the Project Approved by the Order of the Ministry of Fuel and Energy of Ukraine of 16.11.2004 \#721. (2004). Kyiv, Ukraine.

[26] Instruction on the Procedure of Liquidation and Conservation of Enterprises Engaged in Mineral Extraction (as for the provision of safety, efficient use, and subsoil protection) approved by the Decree of Gostekhnadzor of the USSR of 11.07.1985 \#28 (NPAON 00.0-5.05-85). (1985). Kyiv, Ukraine.

\section{Особливості правового забезпечення експлуатації малих нетипових} вугільних шахт на договірних умовах державно-приватного партнерства

\section{Р. Кірін, С. Грищак, О. Илларіонов}

Мета. Дослідження і розробка господарсько-правової моделі малих нетипових вугільних шахт на основі аналізу досвіду їх експлуатації на договірних умовах державно-приватного партнерства, а також відповідного правового та технологічного забезпечення в умовах тиску внутрішніх і зовнішніх факторів.

Методика. Дослідження виконано із використанням економіко-правового підходу, що полягає в оцінці фактичної технікоекономічної діяльності двох суб'єктів господарювання: малої нетипової вугільної шахти і державного вугледобувного підприємства, виявлення проблем в їх взаємовідносинах, встановлення перешкод для співпраці. Другою складовою зазначеного підходу $є$ аналіз доступних (легальних) механізмів правового регулювання відносин між двома зазначеними суб'єктами господарювання та формулювання відповідних пропозицій до висновку такого виду господарського договору, який би задовольняв потреби і враховував інтереси держави й приватного інвестора (партнера).

Результати. Встановлено, що укладання господарського договору в умовах, що склалися, технічної та організаційно-правової залежності експлуатації малої нетипової вугільної шахти і передбачуваної ліквідації державного вугледобувного підприємства $є$ можливим на умовах і в порядку, визначеному законодавством України. Обгрунтовано вибір виду договору про взаємне надання послуг з необхідними додатками, що забезпечують нормалізацію виробничої діяльності, контроль техніки безпеки, а також мінімізацію соціально-економічних наслідків передбачуваної консервації (ліквідації) неперспективних шахт. 
Наукова новизна. Розроблено нову модель правового забезпечення створення та експлуатації малих нетипових шахт, яка в представленому вигляді не знаходила свого розвитку в науковій літературі як в Україні, так і за кордоном.

Практична значимість. Результати дослідження можуть використовуватися в розвитку підприємницьких відносин у вугільній галузі - створення малих нетипових вугільних шахт і вирішення гострих соціально-економічних, інвестиційних та екологічних питань вугледобувних регіонів України з неперспективними гірничими об'єктами, а також у сприянні впливу на зміст концепції реформування вугільної галузі і плану заходів по їі реалізації.

Ключові слова: мала нетипова вугільна шахта, державне вугледобувне підприємство, державно-приватне партнерство, договірні умови

\section{Особенности правового обеспечения эксплуатации малых нетипичных угольных шахт на договорных условиях государственно-частного партнерства}

\section{Р. Кирин, С. Грищак, А. Илларионов}

Цель. Исследование и разработка хозяйственно-правовой модели малых нетипичных угольных шахт на основе анализа опыта их эксплуатации на договорных условиях государственно-частного партнерства, а также соответствующего правового и технологического обеспечения в условиях давления внутренних и внешних факторов.

Методика. Исследование выполнено с использованием экономико-правового подхода, заключающегося в оценке фактической технико-экономической деятельности двух субъектов хозяйствования: малой нетипичной угольной шахты и государственного угледобывающего предприятия, выявления проблем в их взаимоотношениях, установлении препятствий для сотрудничества. Второй составляющей указанного подхода является анализ доступных (легальных) механизмов правового регулирования отношений между двумя указанными субъектами хозяйствования и формулирование соответствующих предложений к заключению такого вида хозяйственного договора, который бы удовлетворял потребности и учитывал интересы государства и частного инвестора (партнера).

Результаты. Установлено, что заключение хозяйственного договора в сложившихся условиях технической и организационноправовой зависимости эксплуатации малой нетипичной угольной шахты и предполагаемой ликвидации государственного угледобывающего предприятия является возможным на условиях и в порядке, определенном законодательством Украины. Обоснован выбор вида договора о взаимном предоставлении услуг с необходимыми приложениями, обеспечивающими нормализацию производственной деятельности, контроль техники безопасности, а также минимизацию социально-экономических последствий предполагаемой консервации (ликвидации) неперспективных шахт.

Научная новизна. Разработана новая модель правового обеспечения создания и эксплуатации малых нетипичных шахт, которая в представленном виде не находила своего развития в научной литературе как в Украине, так и за рубежом.

Практическая значимость. Результаты исследования могут использоваться в развитии предпринимательских отношений в угольной отрасли - созданию малых нетипичных угольных шахт и решении острых социально-экономических, инвестиционных и экологических вопросов угледобывающих регионов Украины с неперспективными горными объектами, а также в оказании влияния на содержание концепции реформирования угольной отрасли и плана мероприятий по ее реализации.

Ключевые слова: малая нетипичная угольная шахта, государственное угледобывающее предприятие, государственно-частное партнерство, договорные условия

\section{Article info}

Received: 3 December 2019

Accepted: 13 May 2020

Available online: 15 May 2020 